\title{
Technology of Multi-stage Sterilization of Raw Materials with the Production of Feed Meal of High Biological Value
}

\author{
Ruslan Maratbekovich Iskakov ${ }^{1 *}$, Assel Maratbekovna Iskakova², Sultanbek \\ Sansyzbaevich Issenov ${ }^{3}$, Dinara Maratbekovna Beisebekova ${ }^{4}$ and Altyngul \\ Kumashevna Khaimuldinova ${ }^{5}$
}

\begin{abstract}
${ }^{1}$ Department of Agrarian Technique and Technology, S.Seifullin Kazakh Agro Technical University, 62 a Prospect Pobedy, Astana, 010000, Republic of Kazakhstan. ${ }^{2}$ Department of Public Health and Evidential Medicine, Semey State Medical University, 103 Abay Street, Semey, 071410, Republic of Kazakhstan. ${ }^{3}$ Department of Electrical Equipment Operation, S.Seifullin Kazakh Agro Technical University, 62 a, Prospect Pobedy, Astana, 010000, Republic of Kazakhstan. ${ }^{4}$ Communal State Public Enterprise "Club of Settlement Shulbinsk", Settlement Shulbinsk, Semey, 071426, Republic of Kazakhstan. ${ }^{5}$ Department of Standartization and Certification, Eurasian National University named after L.N. Gumilyov, 2 Satpayev Street, Astana, 010000, Republic of Kazakhstan.
\end{abstract}

\begin{abstract}
The article is devoted to the study of the sterilization of waste materials and animal feed meal. It was revealed that at the last stage of waste processing of animal origin, as a result of fine grinding in the crusher, feed meal of low biological value is obtained. As a result of research, a technology of multistage sterilization of raw materials has been developed with obtaining feed meal of animal origin of high biological value due to cooking-sterilization (stage 1), drying-sterilization (stage 2), steam sterilization (stage 3). As a result of the final sterilization, i.e. steam sterilization of feed meal from animal waste revealed that when the temperature drops below $110^{\circ} \mathrm{C}$ and sterility is not achieved when the warm-up time is less than 25 minutes and when the temperature rises above $134{ }^{\circ} \mathrm{C}$ and the warm-up time is more than $\mathbf{5 0}$ minutes, the degradation of the sterilized materials begins. It is revealed that the total number of microbes in $1 \mathrm{~g}$ of flour is completely eliminated due to the use of multistage sterilization technology.
\end{abstract}

Keywords: Animal feed meal, sterilization, bacteria.

*Correspondence: rus.iskakov79@mail.ru; +87051164648

(Received: 18 February 2019; accepted: 20 March 2019)

Citation: Ruslan Maratbekovich Iskakov, Assel Maratbekovna Iskakova, Sultanbek Sansyzbaevich Issenov, Dinara Maratbekovna Beisebekova and Altyngul Kumashevna Khaimuldinova, Technology of Multi-stage Sterilization of Raw Materials with the Production of Feed Meal of High Biological Value, J Pure Appl Microbiol., 2019; 13(1):307-312 doi: 10.22207/JPAM.13.1.33

(C) The Author(s) 2019. Open Access. This article is distributed under the terms of the Creative Commons Attribution 4.0 International License which permits unrestricted use, sharing, distribution, and reproduction in any medium, provided you give appropriate credit to the original author(s) and the source, provide a link to the Creative Commons license, and indicate if changes were made. 


\section{INTRODUCTION}

Due to their biological usefulness, raw materials and feed of animal origin are a good nutrient medium for the development of various microorganisms. Despite the fact that the mode of sterilization of raw materials for the production of feed guarantees obtaining semi-finished products (shkvara), free from pathogenic forms of microorganisms, in the domestic and foreign literature reports on the contamination of feed by bacteria of the group of E. coli, Salmonella, toxigenic anaerobes are reported ${ }^{1-4}$. To date, the effect on feed meal of animal origin of high bacterial contamination has not been studied enough. Meanwhile, the presence of various bacteria in the feed meal of animal origin can provoke various diseases with the necessary involvement of medical and social assistance services ${ }^{5}$ and adversely affect the productivity of farm animals and birds. Therefore, one of the main requirements for the quality of feed meal of animal origin is to obtain feed meal of animal origin of high biological value.

\section{MATERIALS AND METHODS}

The research materials were: cookingsterilization (stage 1), drying-sterilization (stage 2 ), steam sterilization (stage 3 ); waste of meat and bone raw materials (meat and bones of hens, mutton, beef and horse meat), including fat-free; feed meal of animal origin after the process of fine grinding in a hammer mill. Studies of cooking were carried out in a digester, and drying in a convective dryer. Experimental studies of steam sterilization were performed in a steam automatic sterilizer (autoclave) SPVA-75-I-HH. In the course of the experiments, the sterilizer control panel controlled the parameters of the sterilization mode (temperature and heating time). The overpressure in the sterilization chamber and the steam generator was monitored by man-vacuum meters. To measure time, a stopwatch was used, accuracy class $\pm 1 \mathrm{~s}$. To measure the consumption of electrical energy, a three-phase electric meter of the type SASU was used, multilimit, accuracy class 2.0. Weighing samples of waste materials and animal feed meal was carried out using electronic scales OHAUS. The determination of the total bacterial contamination of waste materials and feed meal of animal origin was carried out by direct sowing. The quality assessment of feed meal from animal waste was carried out by standard methods: sampling and test methods of feed meal of animal origin according to the current standard ${ }^{6}$; sampling, sample preparation and bacteriological analysis of feed meal of animal origin according to the current standard?

\section{RESULTS}

In the process of conducting scientific experiments conducted research steam sterilization. We note that in the previously developed technology, cooking was more intensive due to high-temperature heating $\left(150-180^{\circ} \mathrm{C}\right)$, drying occurred due to fast (30-50 seconds, $10-20$ $\mathrm{m} / \mathrm{s})$ and high-temperature blowing $\left(250-300^{\circ} \mathrm{C}\right)$ dried particles ${ }^{8-9}$. However, after further fine grinding, the achieved sterility was lost. In this connection, we have proposed steam sterilization at the final stage of processing of waste raw materials, i.e. after the fine grinding process.

Fig. 1 shows the scheme of the developed technology for processing waste materials of animal origin, aimed at improving the quality of sterilization of animal waste.

The technical result is a reliable technology of sterilization of flour from animal waste (included in the technology of multi-stage sterilization of animal waste and processing technology of animal waste material), which improves the quality of decontamination of feed flour from animal waste.

The principle of operation of the developed technology for processing waste materials of animal origin focuses on improving the quality of sterilization. In accordance with Fig. 2, the scheme of the technology of multistage sterilization of animal waste is presented. Sterilization stage 1 occurs in a compact digester when combined with a high-temperature cooking process. Here we can note the short duration of the cooking process, which does not reduce the biological value of raw materials, unlike analogs. Stage 2 sterilization occurs when combined with the process of convective drying in the vortex space. It should also be noted the intensity of the drying process due to the increased feed rate of the drying agent, increased heating temperature of the drying agent and the transported drying object - animal waste material when interacting with the drying agent, which guarantees both sterility and 


\begin{tabular}{|c|}
\hline Coarse crushing of animal waste in a power shredder \\
\hline $\begin{array}{c}\text { Magnetic capture of metal particles in pre-crushed waste } \\
\text { materials of animal origin using a metal trap }\end{array}$ \\
\hline $\begin{array}{c}\text { Cooking and stage } 1 \text { sterilization of pre-crushed waste } \\
\text { materials of animal origin to obtain fat in the digester }\end{array}$ \\
\hline \begin{tabular}{|} 
Squeezing of fat-free, wet, pre-crushed waste raw \\
materials of animal origin in the drainage device with \\
draining the broth in the drive
\end{tabular} \\
\hline Drying and Stage 2 sterilization of non-fat, wet, \\
pre-crushed animal waste in the dryer \\
\hline Fine grinding of dry, defatted, pre-crushed waste materials \\
of animal origin in the crushed to produce feed meal \\
\hline
\end{tabular}

Fig. 1. Diagram of technology for processing waste materials of animal origin

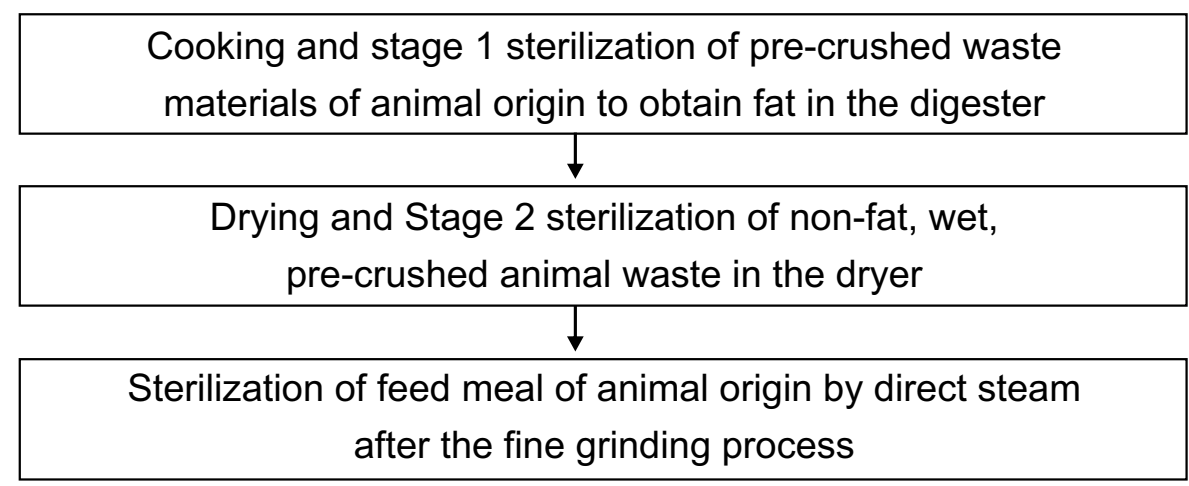

Fig. 2. Diagram of the technology of multi-stage sterilization of animal waste

biological value of dried animal raw materials. The last technological process in the processing of waste materials of animal origin is fine grinding, which reduces the achieved sterility. Therefore, in the last stage of processing, the obtained feed meal of low biological value is subjected to steam sterilization, which significantly increases the biological value of feed meal of animal origin. 


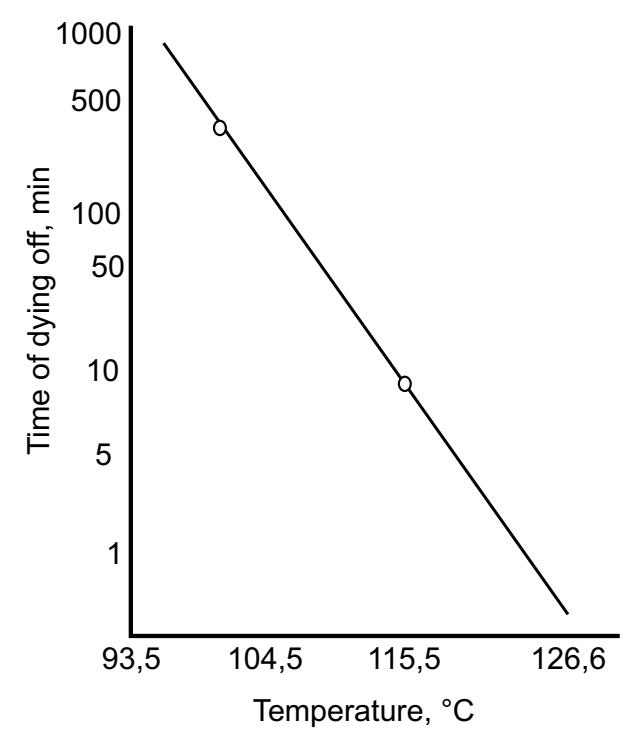

Fig. 3. Dependence of dying time on temperature in semi-logarithmic coordinates

\section{DISCUSSION}

A properly selected and scientifically based sterilization regime (temperature and duration of its effect) should guarantee the high quality of feed meal from animal waste with a certain degree of sterility. The extinction conditions for this type of microorganism are always determined by the ratio "temperature time".
For each type of microorganism, there is an inverse relationship between the time of dying and temperature with the same sterilizing effect, i.e. with an increase in the temperature of sterilization, the time of dying decreases in a geometrical progression. In semi-logarithmic coordinates, this dependence appears as a straight line (f. 3 ) and can be characterized by the mathematical expression

$$
\lg (\mathrm{y} / \mathrm{t})=\mathrm{x} / \mathrm{z}
$$

On the basis of the considered expression, it is only possible to theoretically determine the time corresponding to any selected sterilization temperature.

The spores die off in stages: in the first (the stage of rapid extinction) more than half of the dispute is destroyed; on the second, the number of viable spores decreases along a logarithmic curve; in the third, the rate of withering away of a small amount of spores remaining decreases.

As a result of sterilization in waste and flour of animal origin, deep destruction of soluble protein substances to polypeptides can occur. At the same time, part of the polypeptides is hydrolyzed to low molecular nitrogenous bases. There are processes of deamination and decarboxylation of some amino acids, accompanied by the destruction and loss of some of them, including essential ${ }^{10}$.

Table 1. Microbiological assessment of the quality of feed meal from animal waste produced by two technologies

\begin{tabular}{|c|c|c|c|c|c|}
\hline No. & Indicators & Unit & $\begin{array}{l}\text { Established } \\
\text { performance } \\
\text { requirements }\end{array}$ & $\begin{array}{l}\text { Technology with } \\
\text { sterilization } \\
\text { in the boiler - } \\
\text { KVM } 4.6 \mathrm{M} \text {, } \\
\text { culminating in } \\
\text { the process of } \\
\text { fine grinding in } \\
\text { the crusher }\end{array}$ & $\begin{array}{l}\text { The technology of } \\
\text { multi-stage } \\
\text { sterilization in the } \\
\text { digester, the dryer, } \\
\text { culminating in } \\
\text { steam sterilization } \\
\text { after fine grinding } \\
\text { in the crusher }\end{array}$ \\
\hline 1 & $\begin{array}{l}\text { The total content } \\
\text { is the number of } \\
\text { microbes in } 1 \mathrm{~g} \text { of } \\
\text { flour }\end{array}$ & m.c./g & $\begin{array}{l}\text { No more than } \\
500000\end{array}$ & 450000 & Not found \\
\hline 2 & $\begin{array}{l}\text { Bacteria of the group } \\
\text { of Escherichia coli }\end{array}$ & - & Not allowed & Not found & Not found \\
\hline 3 & $\begin{array}{l}\text { Bacteria of the genus } \\
\text { Salmonella }\end{array}$ & - & Not allowed & Not found & Not found \\
\hline 4 & Anaerobic bacteria & - & Not allowed & Not found & Not found \\
\hline
\end{tabular}


During the experiments, more attention was paid to steam sterilization of feed meal from animal waste, since sterilization of animal wastes at the stages of boiling and drying was achieved in sufficient volume in previous studies ${ }^{11}$.

In the experiments, the temperature of heating with steam $\left(110-134^{\circ} \mathrm{C}\right)$ of flour from animal waste and the dwell time (25-50 $\mathrm{min}$ ) of flour from animal waste at heated temperatures $\left(110-134^{\circ} \mathrm{C}\right)$ were varied. Comparative experiments were carried out on samples of flour from animal waste (after fine grinding in a crusher), samples of flour from animal waste (after fine grinding in a crusher and steam sterilization). The range of variable parameters was chosen based on the experience of sterilizers used to sterilize identical materials. To eliminate the effect of random errors, experiments were performed in triplicate.

Table 1 presents comparative data of experiments using animal waste processing technology, culminating in fine grinding and processing technology of animal waste with multistage sterilization using final sterilization with a pair of flour particles from animal waste after the fine grinding process, in particular, the total content is the number of microbes in $1 \mathrm{~g}$ of flour, bacteria of the group of Escherichia coli, bacteria of the genus Salmonella, Anaerobic bacteria in flour samples.

From table 1 it can be seen that the total number of microbes in $1 \mathrm{~g}$ of flour was not detected in flour from animal waste produced according to the technology with multistage sterilization in the digester, dryer, which ends in steam sterilization after fine grinding in the crusher. At the same time, the total number of microbes in $1 \mathrm{~g}$ of flour produced using the technology of sterilization in the KVM-4,6M boiler, culminating in the fine grinding process in the crusher, is 450,000 m.c./g, which indicates a significantly lower sterilization of feed relative to technology with multi-stage sterilization in the digester, the dryer, culminating in steam sterilization after fine grinding in the crusher. The table also shows the absence of bacterial growth of the coliform group, the absence of bacteria from the genus Salmonella, the absence of anaerobic bacteria in feedstuff samples from animal waste produced using multistage sterilization technology in a digester, dryer, which ends in steam sterilization after fine grinding in a crusher and technologies with sterilization in the boiler KVM-4, 6M, culminating in the process of fine grinding in the crusher.

Data from laboratory studies are consistent with the results of scientists ${ }^{12}$, who believe that the optimal conditions for preserving the biological value of products subjected to sterilization are higher heating temperatures and at the same time reducing the heat treatment time. As a result of sterilization of feed meal from animal waste, it should be noted that when the temperature drops below $110^{\circ} \mathrm{C}$ and the warmup time is less than $25 \mathrm{~m}$, sterility is not achieved, and when the temperature rises above $134^{\circ} \mathrm{C}$ and the warm-up time is more than 50 minutes. the degradation of the sterilized materials begins. This is most likely due to the fact that the heat treatment of raw materials of animal origin has a significant impact on the state of muscle tissue proteins, causing a change in the ratio of various forms of nitrogen that have not the same biological value.

\section{CONCLUSION}

It is revealed that the total number of microbes in $1 \mathrm{~g}$ of flour is completely eliminated using the technology of multistage sterilization in the digester, the dryer, which ends in steam sterilization at a temperature of $110-134^{\circ} \mathrm{C}$ with simultaneous heating time of 25-50 minutes. after fine grinding in a crusher.

\section{ACKNOWLEDGEMENTS}

Authors of this article always keep in mind and thank for valuable advice and support a distinguished scholar and, honored worker of education and the best teacher of the Republic of Kazakhstan, winner of multiple scientific competitions, Doctor of veterinary, Professor, Academician Maratbek Mukhabekovich Iskakov. Cherished memory of him will always be in the hearts of all decent people.

\section{CONFLICTS OF INTEREST}

The authors declare that there is no conflict of interest.

\section{REFERENCES}

1. Iskakov, M.M. and R.M. Iskakov. Topicality of Veterinary at the Feed Production. (in Russian) // Agricultural 
Science - to Agriculture: Collection of Articles of the 3-rd International Research-to-practice Conference, 2008; Vol. 2, Barnaul, March 12th-13th, 2008 / Altai State Agrarian University - Barnaul - Russia, pp: 304306.

2. Iskakov, M.M. and R.M. Iskakov. Veterinary condemned materials and their processing. (in Russian): Almaty Meshdunarodnoe Agentstvo Podpiski, 2011; pp: 216.

3. Iskakov, M.M. and R.M. Iskakov. Veterinary and Sanitary State of Feed Wastes of Food Industry and Evaluation of the Manufactured Product (in Russian) // Parasitocenology: Current State of Knowledge, Topical Issues and Ways of Solution: Materials of International Research-to-practice Conference, Semey, Octomber 29th-30th, 2006 / Semipalatinsk state university named after Shakarim - Semey -Republic of Kazakhstan, 2006; pp. 290-294.

4. Limarenko, A.A., I.C. Dubrov, A.A. Taimasukov and C.N. Zabachta. Diseases of Agricultural Birds. (in Russian). St. Petersburg: Lan, 2005; pp: 448.

5. Iskakova, A.M., Abzalova, R.A. and Beisebekova, D.M. Analysis of Medical and Social Technologies in Nursing at the Level of Primary Health Care. Biology and Medicine, 2015; 7(4): 5.

6. GOST 17681-82. Feed Meal of Animal origin. Selection of Samples and Testing Methods. - Introduction 1983-
07-01. (in Russian). Moscow: State Committee of the USSR on Standardization: Publ. stand., 1986. -23 p.

7. GOST 25311-82. Feed Meal of Animal Origin. Methods of Bacteriological Analysis. - Introduction 1983-07-01. (in Russian). - Moscow: State Committee of the USSR on Standardization: Publ. stand., 1982. - 9 p.

8. Iskakov, R.M., Issenov, S.S., Iskakova, A.M., Halam, S. and Beisebekova, D.M. Microbiological Appraisal of Feed Meal of Animal Origin, Produced by Drying and Grinding Installation. Journal of Pure and Applied Microbiology, 2015; 9(1): 587-592.

9. Issenov, S.S., and Pyastolova, I.A. Mathematical Model of Automatic Control System for Asynchronous Multimotor Drive. Electronics and Electrical Engineering, 2012; 18(8): 9-12.

10. Kezelachvili D.V. Technology of meat and meat products. Part 3. (in Russian). Kemerovo technological institute of food industry, 2004; pp: 115.

11. Iskakov, R.M., Issenov, S.S., Iskakova, A.M., Halam, S. and Beisebekova, D.M. (2013). Heat-and-Moisture Transfer at the Feed Meal Particles Drying and Grinding. Life Science Journal, 10(12s): 497-502.

12. Ivachov, V.I., Snizar, A.I. and Chernuha, I.M. Biotechnology and Assessment of Quality of Animal Forages. (in Russian). Moscow: Agropromizdat, 1991; pp. 52. 